\title{
KRONIKA
}

\author{
Matgorzata Frydrych \\ Katedra Geografii Fizycznej \\ Wydział Nauk Geograficznych, Uniwersytet Łódzki
}

\section{OGÓLNOPOLSKA KONFERENCJA NAUKOWA „GIS DZIŚ”, KRAKÓW, 17-18.11.2014}

\section{NATIONWIDE SCIENTIFIC CONFERENCE “GIS TODAY”, KRAKÓW, 17-18.11.2014}

W dniach 17-18.11.2014 w Uniwersytecie Pedagogicznym im. Komisji Edukacji Narodowej w Krakowie odbyła się Konferencja Naukowa „GIS DZIŚ". Została ona zorganizowana po raz drugi przez Studenckie Koło Naukowe Geografów oraz Instytut Geografii UP im. KEN. Ideą konferencji była prezentacja możliwości jakie niesie wykorzystanie najnowszych narzędzi GIS w badaniach środowiska. Nad organizacją oraz poziomem merytorycznym konferencji czuwał Komitet Naukowy pod przewodnictwem dr Tomasza Bryndala. W jego skład wchodzili również: dr Rafał Kroczak - Zastępca Przewodniczącego Komitetu Naukowego, prof. dr hab. Roman Soja, dr Piotr Dolnicki, dr Wioletta Kilar, dr Paweł Struś, dr Radosław Uliszak oraz dr inż. Witold Warcholik. Komitetowi Organizacyjnemu przewodniczyła Gabriela Bołoz, a funkcję sekretarza konferencji pełniła Bernadetta Jarząbek. Patronat honorowy nad konferencją objął prof. dr hab. Michał Śliwa - JM Rektor Uniwersytetu Pedagogicznego w Krakowie.

Materiały konferencyjne zostały przygotowane pod redakcją Agnieszki Babiarz oraz Moniki Byrskiej i zawierają 37 abstraktów wystąpień. Organizatorzy planują wydanie monografii zawierającej artykuły powstałe na podstawie referatów. Wśród prelegentów dość licznie wystąpili przedstawiciele Studenckiego Koła Geografów oraz Instytutu Geografii UP im. KEN w Krakowie. Swoje reprezentacje posiadały również inne jednostki: Uniwersytet Śląski, Uniwersytet Rolniczy im. Hugo Kołłątaja w Krakowie, Uniwersytet Mikołaja Kopernika w Toruniu, Uniwersytet Marii Skłodowskiej-Curie w Lublinie, Instytut Geografii i Przestrzennego Zagospodarowania Polskiej Akademii Nauk w War- 
szawie, Instytut Geografii i Przestrzennego Zagospodarowania Polskiej Akademii Nauk w Krakowie, Wojewódzki Inspektorat Ochrony Środowiska Województwa Małopolskiego, Uniwersytet Łódzki, Politechnika Łódzka oraz Akademia Górniczo-Hutnicza im. Stanisława Staszica w Krakowie. Wśród prelegentów oraz autorów posterów znaleźli się również przedstawiciele Wydziału Geografii Narodowego Uniwersytetu im. Iwana Franki we Lwowie oraz Instytutu Zoologii im. I.I. Schmalhausena Narodowej Akademii Nauk Ukrainy w Kijowie.

W czasie dwóch dni obrad odbyła się jedna sesja plenarna, sesja posterowa i 7 paneli tematycznych:

- GIS - metody badań i obszary zastosowań,

- zastosowania GIS w planowaniu i gospodarce przestrzenią,

- zastosowania GIS w monitoringu i ochronie środowiska,

- zastosowania GIS w badaniach naukowych,

- bazy danych i Infrastruktura Informacji Przestrzennej,

- funkcje i modele danych przestrzennych,

- zastosowania skanowania laserowego LiDAR.

W pierwszym dniu odbyła sie sesja plenarna, podczas której nastąpiło uroczyste rozpoczęcie konferencji oraz wystąpienia przedstawicieli Instytutu Geografii UP im. KEN. W planach było również połączenie się z Polską Stacją Polarną Hornsund i wystąpienie Andrzeja Araźnego, Kierownika 37. Wyprawy Polarnej, co jednak zostało uniemożliwione przez brak łączności spowodowany niekorzystnymi warunkami atmosferycznymi. Pierwszy blok tematyczny zatytułowany „GIS - metody badań i obszary zastosowań” obejmował zagadnienia związane $\mathrm{z}$ kształceniem multimedialnym w praktyce szkolnej, tworzeniem wielowymiarowych modeli budowy geologicznej, wykorzystaniem geomatyki do budowy modeli 3D oraz wykorzystaniem geoinformacji w badaniach nad ścieżkami turystycznymi. Podczas kilkuminutowych wystąpień w ramach sesji posterowej autorzy prezentowali wyniki badań uzyskanych przy wykorzystaniu narzędzi GIS. Podczas drugiego bloku tematycznego „Bazy danych i Infrastruktura Informacji Przestrzennej" zaprezentowano przykłady tworzenia różnorodnych baz danych oraz platform informacyjnych. Wieczorem na terenie Starego Miasta odbyła się gra miejska, podczas której uczestnicy wykonywali zadania kierując się współczesnymi oraz historycznymi mapami miasta. Pierwszy dzień konferencji zakończyło spotkanie integracyjne.

Drugi dzień konferencji rozpoczął trzeci blok tematyczny „Zastosowanie GIS w badaniach naukowych", który poświęcony był prezentacji wyników badań uzyskanych metodami geoinformacyjnymi (np. „Teledetekcyjne metody monitoringu wieloletniej zmarzliny na Svalbardzie", P. Dolnicki). Czwarty blok „Zastosowania modeli danych przestrzennych” prezentował możliwości wykorzystania modelowania w badaniach przyrodniczych (np. modelowanie wezbrań) oraz planistycznych. Został również poruszony problem wpływu typu transformacji przestrzennej na sposób prezentacji danych geograficznych. Kolejny panel tematyczny „Zastosowanie skanowania laserowego LiDAR” poświęcony 
był wykorzystaniu danych LiDAR w badaniach nad rzeźbą terenu oraz aktywnością procesów stokowych. Ciekawym przykładem zastosowania naziemnego skaningu laserowego był przedstawiony projekt modelowania 3D Dębu „Bartek”. Szósty blok „Zastosowanie GIS w monitoringu i ochronie środowiska" obejmował szeroką gamę tematów począwszy od wykorzystania narzędzi GIS do oceny jakości powietrza po analizę procesów hydrologicznych. Ostatni, siódmy blok tematyczny został poświęcony analizom przestrzennym i nosił tytuł ,Zastosowanie GIS w planowaniu i gospodarce przestrzenią”.

Referaty przedstawione na Konferencji „GIS DZIŚ” prezentowały wysoki poziom merytoryczny i zapoczątkowały wiele ożywionych dyskusji. Organizacja wydarzenia była bardzo przemyślana i widać było znaczne zaangażowanie organizatorów w zachowanie odpowiedniego poziomu konferencji, jak i miłej atmosfery. Bardzo duża różnorodność stosowanych narzędzi GIS oraz tematów badawczych, w których zostały one wykorzystane i zaprezentowane na konferencji, świadczy o ogromnych możliwościach, jakie wnoszą one do nauki. W ostatnich latach, w obrębie wielu dyscyplin geografii fizycznej, np. w geomorfologii, paleogeografii czwartorzędu czy geoekologii odnotowuje się daleko idące zmiany $w$ podejściu naukowym. Obrazem tego są coraz to nowsze i bardziej zaawansowane metody badawcze lub sposoby prezentacji wyników. Ciągły postęp w dziedzinie metod geoinformacyjnych, zwłaszcza z zakresu GIS sprawia, że każdą okazję do wymiany doświadczeń, w tym i tę konferencję, należy uznać za bardzo użyteczną, w szczególności dla młodych badaczy i studentów.

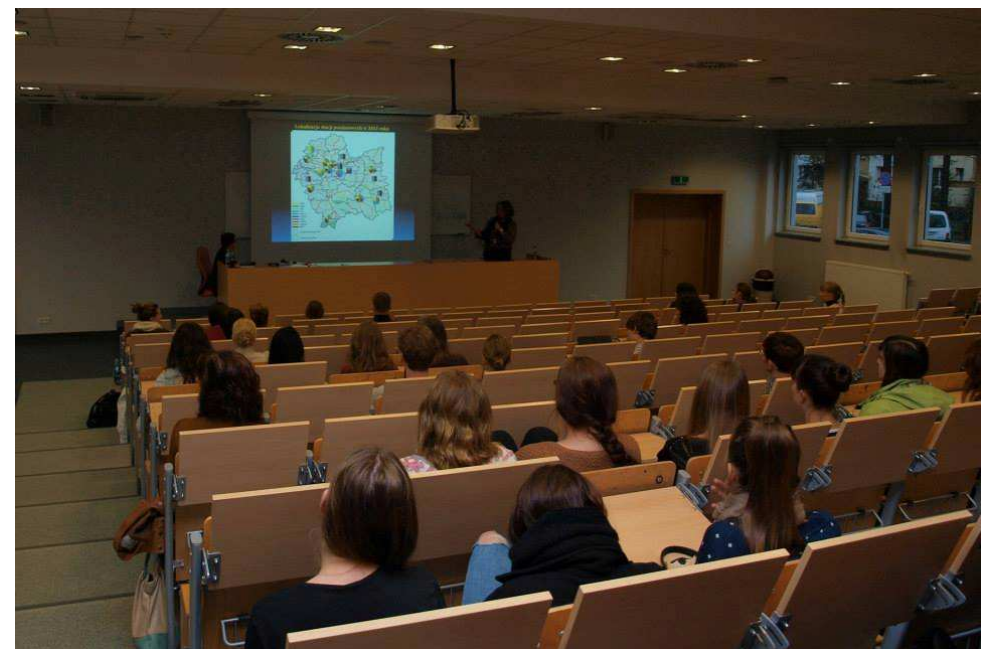

Fot. 1. Konferencja „GIS DZIŚ” na Uniwersytecie Pedagogicznym im. KEN w Krakowie

(fot. W. Jucha, 17.11.2014) 


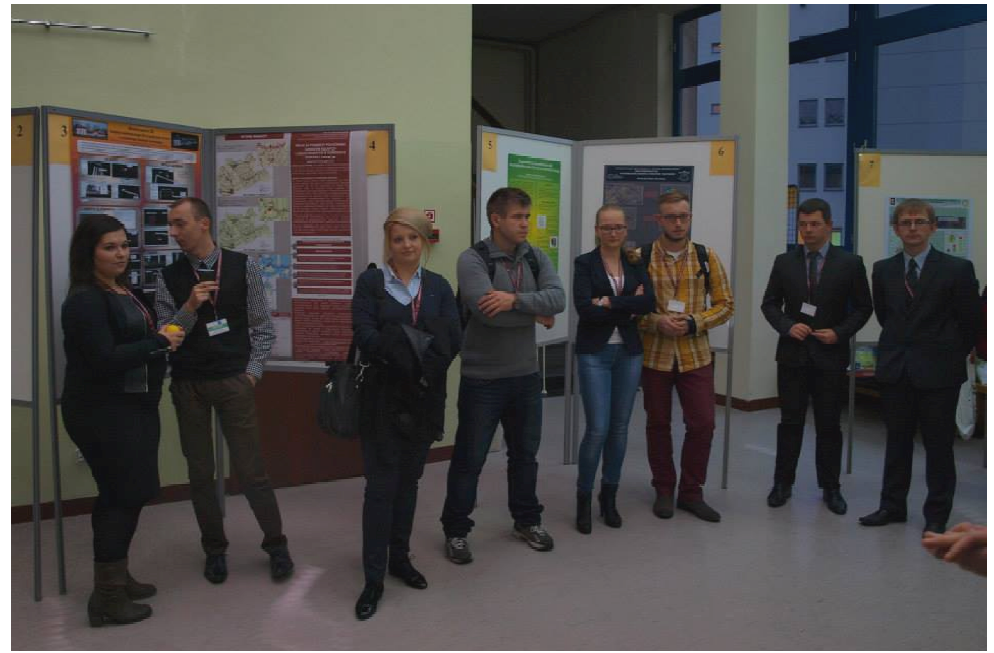

Fot. 2. Sesja posterowa podczas konferencji

(fot. W. Jucha, 17.11.2014)

\section{LITERATURA}

Babiarz A., Byrska M. (red.), Materiaty konferencyjne „GIS DZIŚ”, 17-18 listopada 2014, Kraków, 79 s.

\section{Źródła internetowe}

http://www.opengis.up.krakow.pl/; dostęp: 28.11.2014.

http://www.gisplay.pl/konferencje/136-konferencje/4934-gis-dzis-w-krakowie.html;

dostęp 28.11.2014 